Book Review: Jack Levin and Julia B. Wiest, Premediated Murder: Why Some People Plan to Kill. $1^{\text {st }}$ Edition. Lanham, MD: Rowman \& Littlefield. 2018. ISBN: 978-1538138977 (Paperback). 180 Pages. \$22.

\author{
Reviewed by David A Blackmon ${ }^{1}$
}

[Article copies available for a fee from The Transformative Studies Institute. E-mail address: journal@transformativestudies.org Website: http://www.transformativestudies.org (C2020 by The Transformative Studies Institute. All rights reserved.]

In the book, The Allure of Premediated Murder, Jack Levin and Julie B. Wiest provide a scholarly analysis of premeditated murder. As long as there has been a written record of events, murder has intrigued society. The struggle to understand why individuals engage in acts of premeditated murder have inevitably thrust some of history's most infamous killers into celebrity status. As a byproduct of reporting incidents of murder, and perhaps a desire to entertain viewers, much misinformation has been reported surrounding acts of murder and what drives these killers to commit such acts.

While it is vital to track and apprehend individuals who commit atrocious acts of premeditated murder, understanding what motivates individuals to commit these crimes may provide information that can assist criminologists in reducing future crimes. Presenting examples of past acts of violence and applicable research, the authors guide the reader through various aspects of premeditated murder.

Utilizing research, the authors begin with the planning phase of murder and lead the reader on a journey of murder that concludes with thoughts on what works and what does not work when dealing with mass murder. Beginning the book with Planning is the Payoff, the authors outline the distinction between spontaneous and premeditated murder and provide several intriguing thoughts on the role that planning plays in premeditated murder.

\footnotetext{
${ }^{1}$ David A Blackmon, holds a master's degree in criminal justice from Lamar University in Beaumont, TX and is a 32-year veteran of the Corpus Christi Police Department in Corpus Christi, TX.
}

1937-0229 (2020 Transformative Studies Institute 


\section{David A Blackmon}

While the actual act of premeditated murder may last only a few minutes, the planning of the murder may last for months or even years. Not unlike other events in life, planning is everything. Whether an individual awakens in the morning and plans for the day, or contemplates their long-term future, planning is required to achieve a desired goal. As outlined by the authors, individuals who commit premeditated murder gain some type of gratification from the planning portion of their attack which is often relived after the act is committed. During the initial planning phase, the killer may rehearse the commission of the act over and over in their head. This continuous mental recall not only allows the killer to fine- tune their plan, but in addition, it is believed mental recall may provide some continued mental stimulation in anticipation of the attack (Murray, 2015). In fantasizing these acts, which often involve lust murders, the killer may utilize various forms of paraphilia to further enhance the fantasy. Prior research on paraphilic disorders has shown that deviant sexual fantasies may influence deviant sexual behavior in serial killers during the actual offending process (Chan, Beauregard, \& Myers, 2015, p. 74).

Further evaluation of the importance of the planning stage of a murder, the authors examine the final preparation of the attack which would include acquiring their killing instruments, the location of attack, and in most cases, how the killer would access the location undetected (Levin \& Wiest, 2018). In the case of the Las Vegas Mass Killer, Stephen Paddack, planning would come in the form of selecting a hotel with a vantage point that would allow him to unleash rage upon 22,000 concert goers. In the attack, Paddock would carry suitcases of guns and over 1,600 rounds of ammunition to his room over a three-day period preceding the attack. In the case of Paddock, the planning stage of his attack would provide a blueprint of how killers often begin planning long before the incident and how careful last-minute preparation and planning goes into an attack. While playing video games such as Call of Duty or Hitman may not mean someone will commit a premeditated murder, the realism of these games may stimulate the mind of individuals who may be susceptible to such thoughts (Atkinson \& Rodgers, 2016).

While individuals who commit murder may do so as a result of some prior incident in their lives or a possible mental psychosis, gaining national recognition has also been found to be a driving force in some of history's most notorious killings. Chapter Two of the book, Going Out in a Blaze of Glory, is perhaps one of the most intriguing portions of the book, as it highlights the need for notoriety when committing these unthinkable acts. Understanding the need for recognition during the 
planning phase of murder, the authors would highlight this oftenimportant aspect of the crime. As outlined in the book, it is not uncommon for mass killers and serial killers to construct diaries and manifestos to create a makeshift autobiography on themselves (Levin \& Wiest, 2018, p. 21). To this end, the media has created what can best be described as star status for many of history's most notorious killers. Because of this, individuals contemplating these types of acts may see the media as a mechanism for immortality.

Expanding upon the role that the media plays in reporting the news, scholars have shown that the type of coverage provided on these attacks may affect how a killer is viewed in society. Making celebrities out of killers, which appears to be a recent trend, often leads to the portrayal of these individuals as handsome, intelligent, white males. More recent research highlights that these portrayals are inaccurate. In fact, black males have been reported to have committed over $50 \%$ of serial killings (Hickey, 2016, p. 5).

In many of these media reported cases, the overall concern and wellbeing of the victim has taken a back seat to the star-like celebrity status given to the killer. Researching how various cultures portray killers, the UK media appears to portray killers as more of a monster with greater attention given to the victim. In contrast, the United States media appears to grant more of a celebrity status to violent offenders (Wiest, 2016). Unfortunately, unscrupulous reporting comes at a price.

While serial killers have long been stigmatized as individuals with mental impairments who are sexual deviants, comprehensive research has proven the reality to be much different. In fact, these individuals do not routinely suffer from mental illness. Rather, most serial killers would fall into the category of psychopathy. Because these individuals are often narcissistic in nature, they lack the ability to be sympathetic or remorseful. For these reasons, psychopaths are usually not amenable to treatment (Jefferson \& Godman, 2014). It has been shown that the power that resides in the ability to choose who lives or dies provides an overwhelming amount of satisfaction to killers. As highlighted in the chapter, Playing God, most potential victims of serial killers come from populations that are vulnerable and less likely to resist (Levin \& Wiest, 2018). These populations, such as runaways, prostitutes and mental patients prove to be easy targets for killers. Reflecting on the Green River serial murder cases, Gary Ridgway would utilize his familiarity on the strip to create encounters that would allow him to control his victims and release his hatred of women toward prostitutes who would be powerless to seek help (Levi-Minzi \& Shields, 2007). In the end, Gary 


\section{David A Blackmon}

Ridgway would see these individuals as little more than property to be discarded, and ones he killed quickly so they would not suffer.

While some argue that killers commit crimes with the underlying desire to get caught, research has shown these beliefs to be inaccurate. By carefully planning their acts and being selective when choosing their victims, killers often work to avoid capture by utilizing a risk versus rewards system when selecting victims of serial murder. Utilizing these tactics, serial killers such as Ted Bundy were able to go undetected for years. This philosophy of eluding capture clearly separates serial killers from mass murderers who seldom give little thought to their apprehension.

In Chapter Three, The Thrill of the Hunt, the authors provide compelling research and case history on why many of society's most notorious killers receive such gratification in the hunt for their victims and from the collection of trophies from their kills. Not unlike great hunters in general, successful serial killers stalk their prey. In doing so, these killers pride themselves in knowing the terrain in which they are hunting and the movements of their prey. While media often portrays serial killers as monsters who wonder aimlessly around the country hoping to pounce on unsuspecting victims, research has shown this not to be factual for most serial killers. As outlined earlier in the book, planning is essential to the success of the kill and plays a substantial role in the gratification of the hunt.

When planning, a home base in which to plan is crucial for a successful hunt. Killers, such as Dennis Radar (BTK), would find comfort in hunting in known areas and would not leave an established geographic killing zone. Dennis Radar would go undetected for many years as he hunted his victims throughout Wichita, KS. Utilizing a term coined by D.K Rossmo, in his paper titled Target Patterns of Serial Murderers, the decay function has shown that as the serial killers hunting zone expands, their chances of success are reduced (Canter, Coffey, Huntley, \& Missen, 2000). For this reason, it is not uncommon for many serial murderers to be localized as opposed to traveling killers. In addition, research has revealed that there are many sociological factors at work before the killings begin. Utilizing the social class theory, killers may feel marginalized in the community they live in and take their hatred out on that geographical area rather than hunting in other areas that would fail to provide the killer with any mental stimulation.

One of the most intriguing aspects of the book would surround the collecting of trophies after the kill. As stated earlier by the authors, the planning phase of a murder is often one of the most pleasurable aspects 
the killer might experience and one that will last much longer that the actual event. Previous studies of serial killers have shown that these individuals may take souvenirs after their killings. These souvenirs were found to provide continued mental stimulation for the offender. Reflecting on past serial killings, Douglas Clark and Carol Bundy, also known as the Sunset Strip Killers, would utilize both a centralized hunting ground technique and the collection of trophies to satisfy their hunger to kill.

In 1886, Krafft-Ebing was reported as being the first person to record that sexually motivated killers' torture, degrade and take trophies from their kills. While some believed that sex was the reason for these killings, the reality has been proven to be much different. In fact, sexual pleasure is not always the driving force behind such acts. For individuals, such as lust killers, postmortem mutilation and sexual acts to further degrade the victim is not uncommon (Knight, 2006). While there have been many studies on why serial killers use sex as an instrument of violence, such as childhood trauma, the primary motive for killings such as these appears to be control over the victim.

Evaluating mental conditions of individuals who commit premeditated murder, the authors effectively highlighted various mental states that may lead one to kill. While insanity is a legal term aimed at determining whether an individual is mentally fit to be held accountable for their actions, the word conjures up images of mentally deranged individuals. As highlighted in chapter four, Mind over Murder, mental states can have many triggers. Among these triggers are events in our lives that may alter our mental perception of reality and may involve both love and hate. The authors' utilization of homelessness provided an intriguing review on how situational conditions have the potential to alter an individual's mental state. Current studies on the relationships between homelessness, mental illness and crime have repeatedly yielded positive results on the relationship between increases in mental illness and the propensity for crime (Fischer, Shinn, Shrout, \& Tsemberi, 2008). Unfortunately, while various forms of psychosis, which may have a propensity to lead to murder, is treatable through medication, the United States has opted to discard many of these individuals who are left to selfmedicate.

Reviewing the section, Seeking Sweet Revenge, the authors provided sobering reminders of how individuals, who may have been bullied as children, may commit horrific acts of violence. Unlike serial killers, individuals who commit mass murder appear to give little regard to what happens after their act is committed. Evaluating mass murders, killers 


\section{David A Blackmon}

may often plan, utilizing previous mass killings in an attempt to increase their expected media coverage of the event with the belief that larger body counts will result in more coverage (Gill, Silver, Horgan, \& Corner, 2017).

In the chapter, Prevention, the authors provide compelling thoughts on how society might reduce the instances of mass murder and serial killing. Particularly noteworthy was the authors' willingness to highlight what they felt worked and what didn't work. In cases of mass shootings, gun control is found to be nonproductive in terms of reducing mass shootings. In contrast, the ability to recognize and address instances of depression in our schools may work to defuse a potential time bomb waiting to explode.

Critiquing the book, while the authors did an effective job of researching the various aspects of premeditated murder, and provided numerous examples of those aspects, more statistical data would have further enhanced the sections. In the section, Playing God, the authors highlight that most victims of serial killings are members of vulnerable populations but provided little statistical data to support this claim (Levin \& Wiest, 2018). Secondly, while female serial killers have finally been acknowledged as concerns in society, the book only briefly touched on an example in the Death for Dollars section. Lastly, while health care killers flourish in our society often going undetected for years aspects of these premeditated serial murders were absent from the book.

Overall, the book The Allure of Premediated Murder is a compendium of cases surrounding various forms of premeditated murder which make it a welcome addition to anyone wanting to further explore and attempt to better understand the motivations of murder. Reading the book, one can see that the book details the dark side of murder by reflecting upon the various killers in history. In addition, the authors effectively highlighted the important role that planning plays in the various aspects of murder. While not without its shortcomings, the research was well thought out and the chapters were arranged in a manner that made the book enjoyable to read.

\section{REFERENCES}

Atkinson, R., \& Rodgers, T. (2016). Pleasure zones and murder boxes: online pornography and violent video games as cultural zones of exception. British Journal of Criminology, 56(6), 1291-1307. https://doi.org/10.1093/bjc/azv113 
Canter, D., Coffey, T., Huntley, M., \& Missen, C. (2000). Predicting Serial Killers' Home Base Using a Decision Support System. Journal of Quantitative Criminology, Vol. 16, No. 40, 457-478. Retrieved from Retrieved from https://search-ebscohost-

com.libproxy.lamar.edu/login.aspx?direct=true $\& d b=e d s j s r \& A N=e d s j s r .419542$ 27\&site=eds-live. https://oi.org/10.1023/a:1007551316253

Chan, H. C., Beauregard, E., \& Myers, W. C. (2015). Single-Victim and Serial Sexual Homicide Offenders: Differences in Crime, Paraphilias and Personality Traits. Criminal Behavior and Mental Health, 25: 66, 66-78. https://doi.org/10.1002/cbm.1925

Fischer, S. N., Shinn, M., Shrout, P., \& Tsemberi, S. (2008). Homelessness, Mental Illness, and Criminal Activity: Examining Patterns Over Time. Am J Community Psychol, 42, 251-265. https://doi.org/10.1007/s10464-008-9210-Z

Gill, P., Silver, J., Horgan, J., \& Corner, E. (May 2017). Shooting Alone: The Pre-Attack Experiences and Behaviors of U.S. Solo Mass Murderers. Journal of Forensic Sciences, Vol. 62 Issue 3, 710-714. https://doi.org/10.1111/1556-4029.13330

Hickey, E. W. (2016). Serial Murderers and Their Victims (7th ed.). Boston, MA: Cengage Learning.

Jefferson, A., \& Godman, M. (May 2014). On Blaming and Punishing Psychopaths. Criminal Law and Philosophy, 1-26. https://doi.org/10.1007/s11572-014-9340-3

Knight, Z. G. (2006). Some thoughts on the psychological roots of the behavior of serial killers as narcissists: an object relations perspective. Social Behavior and Personality, 34 (10), 1189-1206. Retrieved from https://search-ebscohost-

com.libproxy.lamar.edu/login.aspx?direct $=$ true $\& \mathrm{db}=\mathrm{s} 3 \mathrm{~h} \& \mathrm{AN}=232185$ 18\&site=eds-live. https://doi.org/10.2224/sbp.2006.34.10.1189

Levi-Minzi, M., \& Shields, M. (January 10, 2007). Serial Sexual Murderers and Prostitutes as Their Victims: Difficulty Profiling Perpetrators and Victim Vulnerability as Illustrated by the Green River Case. Lynch School of Education, Graduate Program in Counseling Psychology, Boston College, 77-89. https://doi.org/10.1093/brieftreatment $/ \mathrm{mhl} 021$

Levin, J., \& Wiest, J. B. (2018). The Allure of Premeditated Murder $\left(1^{\text {st }}\right.$ ed.). Lanham, MD: Rowman \& Littlefield.

Murray, J. L. (October 23, 2015). The Role of Sexual, Sadistic, and Misogynistic Fantasy in Mass and Serial Killing. Deviant Behavior, Vol. 38, No. 7, 735-743. https://doi.org/10.1080/01639625.2016.1197669 
Wiest, J. B. (2016). Casting Cultural Monsters: Representations of Serial Killers in U.S.and U.K.News Media. Howard Journal of Communications, Vol.27, No. 4, 327-346. https://doi.org/10.1080/10646175.2016.1202876 